https://nv.nltu.edu.ua

https://doi.org/10.36930/40310114

$@$ Correspondence author

Article received 28.01.2021 p.

Article accepted 04.02.2021 p.

V. B. Shepitchak

UDC 697.92

\title{
NATURAL RESEARCH OF THE THERMAL PROCESS ON THE SURFACE OF IRRADIATION BY INFRARED HEATER
}

Comfortable conditions for people to stay in the production room with the use of infrared emitters depend on the uniform distribution of temperatures over the entire area of the irradiation zone. Therefore, the purpose of the research was to determine experimentally the temperature on the irradiation surface with an infrared heater and to summarize the results, for their further use in the design of infrared heaters in various production facilities. The distribution of temperatures on the irradiation surface was determined by the method of experimental studies. To derive the patterns of temperature field distribution on the irradiation surface, the experiment was carried out at variable power of the infrared heater $Q_{\text {heat }}, \mathrm{W}$, the height of its installation $H, \mathrm{~m}$ and different blackness degrees of the floor surface $\varepsilon_{f l o o r}$, which depends on the floor material. The graphical distribution can prove the regularity of that heat in solid materials is distributed due to thermal conductivity - from particles with higher temperatures to less heated. Using mathematical methods of experimental data processing, experimental dependences were approximated to determine the relative temperature of the irradiation surface. The temperature gradient obtained graphically is directed along the normal to the isothermal surface in the direction of increasing temperature. This approach enables considering the development of process in the dynamics and allows the visualization of heating to adjust the basic parameters of process. Scientific results obtained in this work will allow developing a new methodological approach to the study of heating processes on the surface of irradiation by an infrared heater on the basis of a combination of physical and mathematical modeling, which can form an instrumental basis for the target study of such processes of formation of the thermal regime in production facilities. The thermal power of the infrared heater $Q_{\text {heat }}$, W had the greatest influence on the value of the relative temperature of the floor surface $t_{f l o o r}$. With constant values of the height of the heater, the blackness degree of the irradiation surface and with increasing the thermal power of the heater twice the value of the relative temperature of the irradiation surface increased by $9.7 \%$.

Keywords: infrared heater; irradiation surface; blackness degree; thermal power of the heater.

\section{Introduction}

Infrared heating systems are modern energy efficient systems, as they have the ability to carry out local heating of surfaces, and later the building as a whole. Therefore, it is advisable to use them in large rooms with excessive heat losses, which are production facilities. Compared to convective heating systems, they are less inertial because they naturally heat surfaces, not air.

The use of infrared heating allows to provide the required temperature in the working area of the production room. It is important to correctly design infrared heating systems, taking into account calculation methods based on modeling heat transfer processes on heated surfaces.

Comfortable conditions of people staing in a production room with use of infrared emitters depend on uniform distribution of temperatures on all area of an irradiation zone.

The object and subject of study. The object of study is the irradiation area with an infrared heater, namely the floor surface of the room. The subject of research - patterns of influence on the surface temperature of variable factors.

Purpose and tasks of the study. The aim of the paper was to determine experimentally the temperature on the irradiation surface with an infrared heater and to summarize the results, for their further use in the design of infrared heaters at various production facilities.

Scientific novelty of the research and practical significance of the obtained results. The thermal power of the infrared heater significantly affects the processes of heat transfer and temperature distribution on the heating surface in stationary conditions.

Research related to modeling the thermal process in infrared heating is extremely relevant. A special place in such studies is occupied by the scientific applied problem of modeling heat treatment of surfaces by infrared heaters, arising from the need to expand the capabilities of the researcher due to the rapid development of field research tools and methods of experimental data processing.

Analysis of Literary Sources. Infrared radiation is electromagnetic radiation that has the same nature as visible

Інформація про авторів:

Сподинюк Надія Андріївна, канд. техн. наук, доцент, кафедра теплоенергетики. Email: n_spoduniuk@meta.ua; https://orcid.org/0000-0002-2865-9320

Шепітчак Володимир Богданович, канд. техн. наук, доцент, кафедра цивільної безпеки. Email: shepitchak@gmail.com; https://orcid.org/0000-0001-5883-548X

Цитування за ДСту: Сподинюк Н. А., Шепітчак В. Б. Натурні дослідження теплового процесу на поверхні опромінення інфрачервоним нагрівачем. Науковий вісник НЛтУ України. 2021, т. 31, № 1. С. 85-88.

Citation APA: Spodyniuk, N. A., \& Shepitchak, V. B. (2021). Natural research of the thermal process on the surface of irradiation by infrared heater. Scientific Bulletin of UNFU, 31(1), 85-88. https://doi.org/10.36930/40310114 
light. The rays are in the spectral region between red visible light and shortwave radiation. In infrared technology, there are three main groups of emitters:
a) shortwave $\lambda=0.74 \ldots 2.5 \mu \mathrm{m}$;
b) medium wave $\lambda=2.5 \ldots 50 \mu \mathrm{m}$;
c) long-wave $\lambda=50 \ldots 1000 \mu \mathrm{m}$.

Each group of emitters corresponds to the degree of surface heating. Shortwave - the maximum temperature on the surface of the emitter is $t_{\text {sur }}>800{ }^{\circ} \mathrm{C}$. Such heaters can be called light (Figure 1) [1].

One of the main advantages of such heaters is that they allow the use of physical principles of radiation to heat only specifically selected areas, excluding the extra cost of heating the entire area of a large room. By means of the aluminum shape which is an element of a design of the radiator, uniform distribution of a heat stream on its surface is carried out.

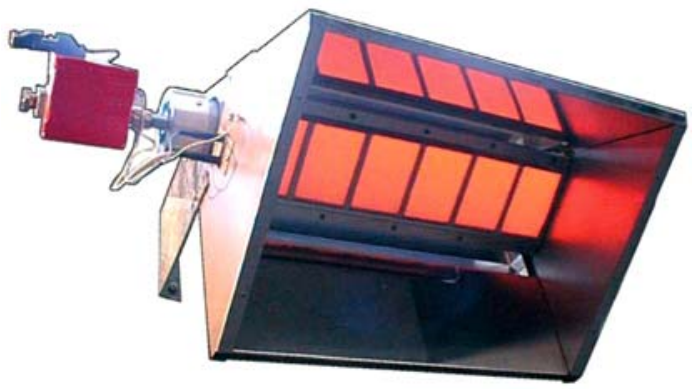

Fig. 1. Light gas heater Carlieuklima S.p. A.

Medium wave - the surface temperature is in the range $t_{\text {sur }}=300 \ldots 600{ }^{\circ} \mathrm{C}$. Such heaters are called gray. Long-wave - surface temperatures are low and in the range $t_{\text {sur }}<300$ ${ }^{\circ} \mathrm{C}$. Such heaters are dark. Dark infrared heaters exist in a tubular shape. They are ideal for medium and large rooms for various purposes (Figure 2) [2].

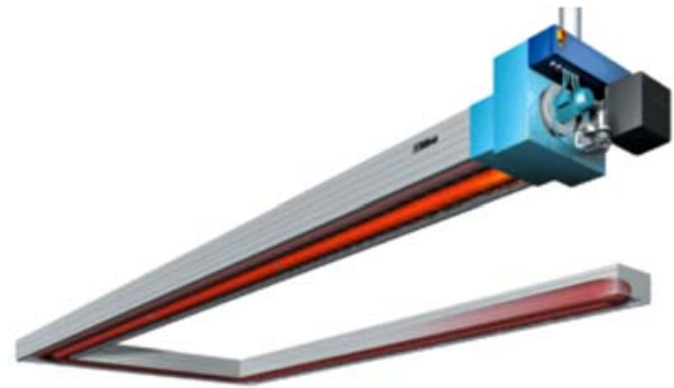

Fig. 2. Dark gas heater Eucerk Carlieuklima S.p. A.

Infrared heating systems are widely used in warehouses, multi-storey warehouses with requirements for maintaining the temperature gradient, factory shops, production facilities, sports complexes, private cottages, garages, residential apartments, medical institutions, conference halls, banks, foyers, premises of agricultural complexes.

Long-wave radiation is completely absorbed by the skin of living organisms and converted into heat, which leads to heating of tissues. Shortwave penetrates deeper into the tissues, with the effect on the end of the autonomic nerve plexuses and blood vessels. Penetrating infrared radiation through blood and nervous system reactions affects glandular function and overall metabolism. Thus the reaction of the general protection of an organism amplifies, the barrier on a way of cold penetration into an organism is created, preventing its supercooling preventing its hypothermia, normalizes the tone of the autonomic nervous system [5]. Infrared radi- ation enhances biological processes in the body, helps to tone, the bodys defenses, has healing properties.

\section{Materials and Methods}

The distribution of temperatures on the irradiation surface was determined by the method of experimental studies. The experimental setup is shown in Figure 3.

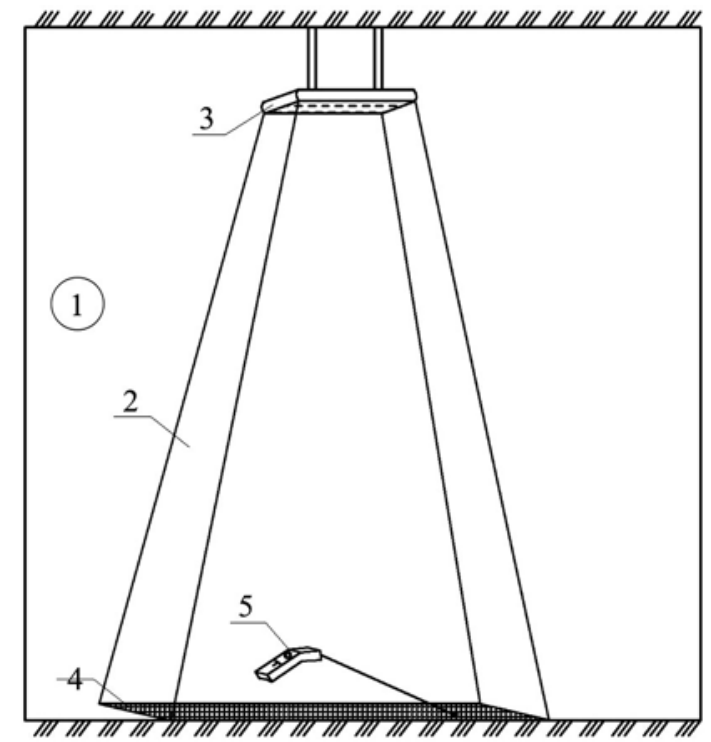

Fig. 3. Experimental stand for research of temperature on the irradiation surface: 1) production premises; 2) irradiation zone;

3) infrared heater; 4) irradiation surface; 5) infrared pyrometer "Nimbus 2000"

To derive the patterns of temperature field distribution on the irradiation surface, the experiment was performed at a variable power of the infrared heater $Q_{\text {heat }}, \mathrm{W}$, the height of its installation $H, \mathrm{~m}$ and different blackness degrees of the floor surface $\varepsilon_{f l o o r}$, which depends on its material. The method of constructing temperature graphs, taking into account the air temperature in the laboratory, is shown in Figure 4. Infrared pyrometer "Nimbus 2000" measured the temperature at various points on the heating surface.

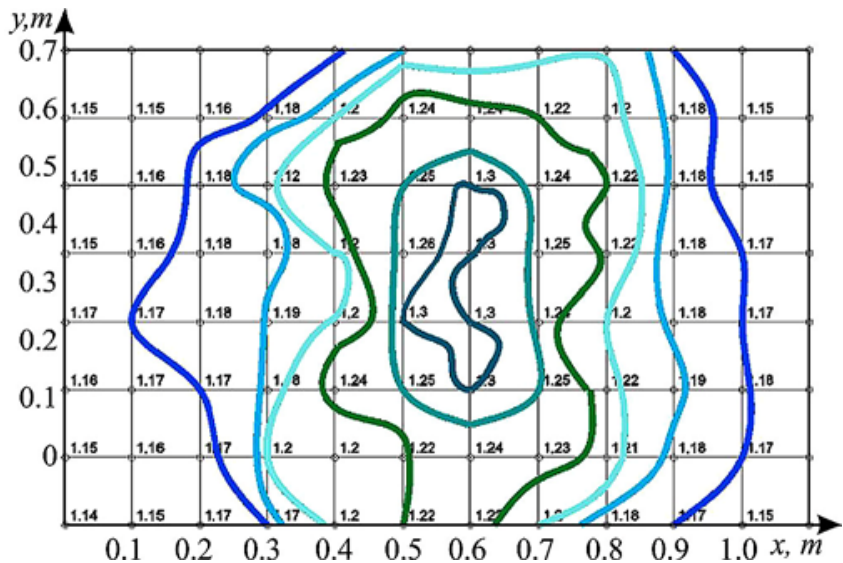

Fig. 4. Values of relative temperatures at experimental points the surface of the metal sheet at $\mathrm{t}_{\mathrm{am}}=17.5^{\circ} \mathrm{C}$

According to the given distribution it is possible to investigate regularity that heat in solid materials is distributed due to thermal conductivity - from particles with higher temperatures to less heated. The process of heat transfer by thermal conductivity in a solid is accompanied by a change in temperature both in space and time [4].

The obtained temperature values were translated into relative values, for which the ratio was determined: 


$$
\bar{t}_{\text {floor }}=\frac{t_{\text {floor }}}{t_{\text {am }}},
$$

where $t_{\text {floor }}$ is the temperature of the heated surface, determined experimentally, ${ }^{\circ} \mathrm{C} ; t_{a m}-$ ambient temperature during the experiment, ${ }^{\circ} \mathrm{C}$.

\section{Research results}

The experiment was carried out taking into account all the important factors influencing the process of heating the floor surface [6]. In Figure 5 shows the graphical dependences of the relative temperature of the heated floor surface $\bar{t}_{\text {floor }}$ from the installation height of the heater $H, m$, the thermal power of the heater $Q_{\text {heat }}, \mathrm{W}$ and for different underlying surfaces with a blackness degree $\varepsilon_{\text {floor }}$.
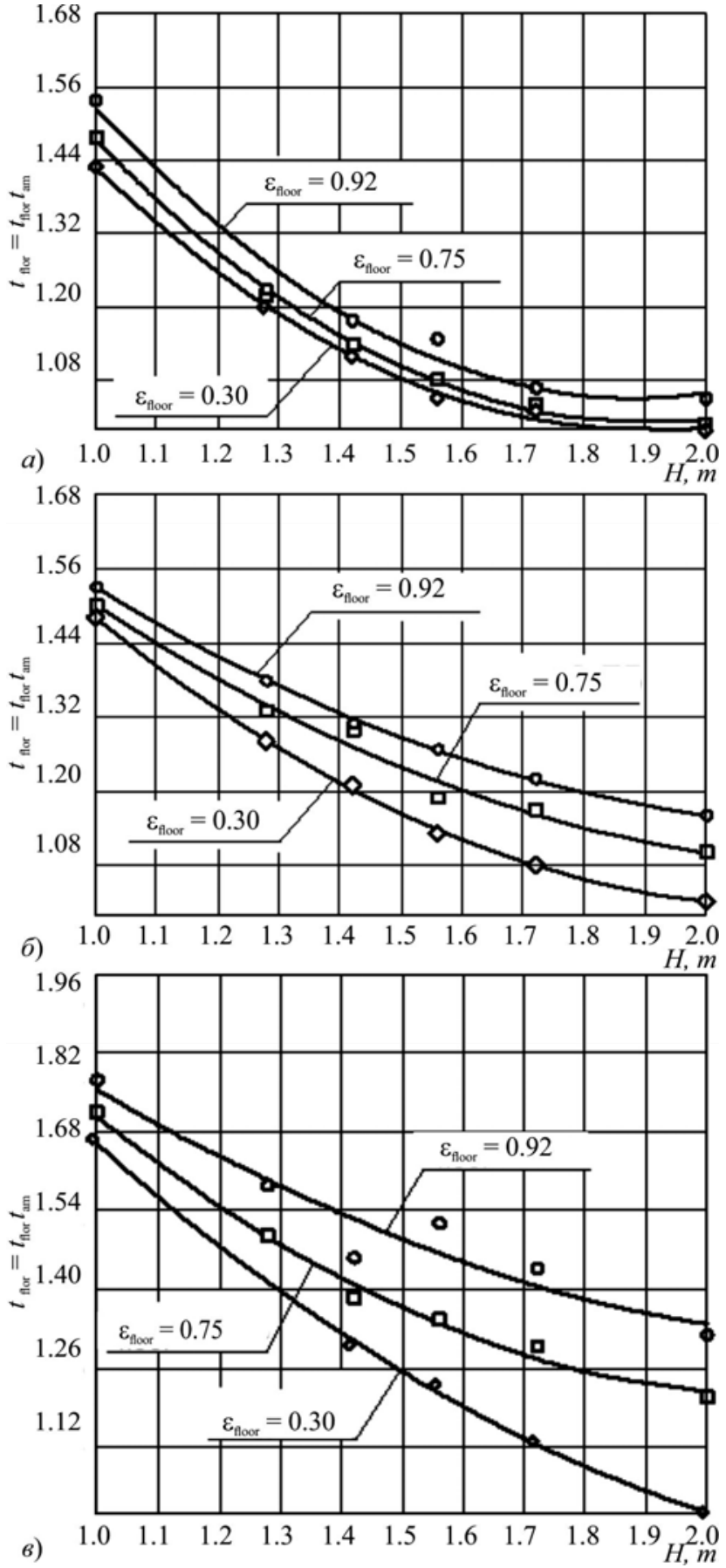

Fig. 5. The dependence of the relative surface temperature of the heated floor $\bar{t}_{\text {floor }}$ from the height of the heater $\mathrm{H}, \mathrm{m}$ at the thermal power of the heater: $\left.a) Q_{\text {heat }}=400 \mathrm{~W} ; b\right) Q_{\text {heat }}=800 \mathrm{~W} ; c$ ) $Q_{\text {heat }}=1200 \mathrm{~W}$
Using mathematical methods of experimental data processing, experimental dependences were approximated to determine the relative temperature of the irradiation surface. At the power of the heater $Q_{\text {heat }}=400 \mathrm{~W}$ the multifactor equation has the form:

$$
\begin{gathered}
\bar{t}_{\text {floor }}=0.11 \cdot \varepsilon_{\text {floor }} \cdot H^{2}+0.5 \cdot H^{2}- \\
-0.39 \cdot \varepsilon_{\text {floor }} \cdot H-1.9 \cdot H+0.45 \cdot \varepsilon_{\text {floor }}+2.8 .
\end{gathered}
$$

At the power of the heater $Q_{\text {heat }}=800 \mathrm{~W}$ will receive:

$$
\begin{gathered}
\bar{t}_{\text {floor }}=-0.19 \cdot \varepsilon_{\text {floor }} \cdot H^{2}+0.4 \cdot H^{2}+ \\
+0.72 \cdot \varepsilon_{\text {floor }} \cdot H-1.7 \cdot H-0.46 \cdot \varepsilon_{\text {floor }}+2.76 .
\end{gathered}
$$

At the power of the heater $Q_{\text {heat }}=1200 \mathrm{~W}$ the equation will take the form:

$$
\begin{gathered}
\bar{t}_{\text {floor }}=-0.067 \cdot \varepsilon_{\text {floor }} \cdot H^{2}+0.35 \cdot H^{2}+ \\
+0.6 \cdot \varepsilon_{\text {floor }} \cdot H-1.83 \cdot H-0.36 \cdot \varepsilon_{\text {floor }}+3.1 .
\end{gathered}
$$

\section{Discussion of the obtained results}

The temperature gradient obtained graphically is directed along the normal to the isothermal surface in the direction of increasing temperature. This approach makes it possible to consider the development of the process in the dynamics and allows the visualization of heating to adjust the basic parameters of the process [3].

The scientific results obtained in this work will allow to develop a new methodological approach to the study of heating processes on the surface of irradiation with an infrared heater on the basis of a combination of physical and mathematical modeling, which can form an instrumental basis for the target study of such processes of formation of the thermal regime in production facilities.

\section{Conclusions}

As can be seen from the graphs and mathematical dependencies, the greatest influence on the relative temperature of the floor surface $\bar{t}_{\text {floor }}$ has a thermal power of the infrared heater $Q_{\text {heat }}, \mathrm{W}$. With constant values of the height of the heater, the blackness degree of the irradiation surface and with increasing the thermal power of the heater twice the value of the relative temperature of the irradiation surface increased by $9.7 \%$.

It is also proved that when heating the surface with the maximum blackness degree, a smooth distribution of the temperature gradient over the entire area of the heated floor is observed. As a result, there is an opportunity to get a uniform heat flow from the heated surface to the working area of the production room, which will improve the comfortable living conditions of people in the room.

\section{References}

1. Dudkiewicz, E., \& Szałański, P. (2020). Overview of exhaust gas heat recovery technologies for radiant heating systems in large halls. Thermal Science and Engineering Progress, 18, 105-152. https://doi.org/10.1016/j.tsep.2020.100522

2. Maznoy, A., Kirdyashkin, A., Pichugin, N., Zambalov, S., \& Petrov, D. (2020). Development of a new infrared heater based on an annular cylindrical radiant burner for direct heating applications. Energy, 204. https://doi.org/10.1016/j.energy.2020.117965

3. Sarbu, I., \& Tokar, A. (2018). Numerical modeling of high-temperature radiant panel heating system for an industrial hall. Int. $J$. Adv. Appl. Sci. https://doi.org/10.21833/ijaas.2018.05.001

4. Shepitchak, V., Zhelykh, V., \& Spodyniuk, N. (2016). Study of peculiarities of surface irradiation with parallel arrangement of infrared heater. Budownictwo o zoptymalizowanym potencjale 


\section{Н. А. Сподинюк ${ }^{1}$ В. Б. Шепітчак ${ }^{2}$}

${ }^{1}$ Начіональний університет біоресурсів і природокористування Украӥни, м. Київ, Украӥна ${ }^{2}$ Національний університет "Львівська політехніка", м. Львів, Украӥна

\section{НАТУРНІ ДОСЛІДЖЕННЯ ТЕПЛОВОГО ПРОЦЕСУ НА ПОВЕРХНІ ОПРОМІНЕННЯ IНФРАЧЕРВОНИМ НАГРІВАЧЕМ}

Комфортні умови перебування людей у виробничому приміщенні із застосуванням інфрачервоних випромінювачів залежать від рівномірного розподілу температур по всій площі зони опромінення. Тому метою роботи $\epsilon$ визначення експериментальним шляхом температури на поверхні опромінення інфрачервоним нагрівачем та узагальнення результатів, для їх подальшого використання у проєктуванні інфрачервоних нагрівачів на різних об'єктах виробничого призначення. Методом експериментальних досліджень визначено розподіл температур на поверхні опромінення. Для виведення закономірностей розподілу температурних полів на поверхні опромінення дослід проведено за змінної потужності інфрачервоного нагрівача

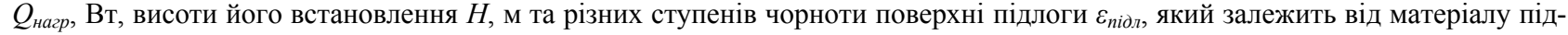
логи. За графічним розподілом можна довести закономірність, що теплота у твердих матеріалах поширюється завдяки теплопровідності - від частинок з більш високою температурою до менш нагрітих. За допомогою математичних методів обробляння експериментальних даних апроксимовано експериментальні залежності для визначення відносної температури поверхні опромінення. Температурний градієнт, отриманий графічно, напрямлений по нормалі до ізотермічної поверхні в бік зростання температури. Такий підхід дає змогу розглядати розвиток процесу в динаміці та здійснювати візуалізацію нагріву для корегування базових параметрів процесу. Отримані у роботі наукові результати дадуть змогу розробити новий методологічний підхід до дослідження процесів нагріву на поверхні опромінення інфрачервоним нагрівачем на засадах поєднання фізичного і математичного моделювання, що може складати інструментальну основу для цільового дослідження подібних процесів формування теплового режиму у виробничих приміщеннях. Найбільший вплив на величину відносної температури поверхні підлоги $t_{n i д л ~}$ мала теплова потужність інфрачервоного нагрівача $Q_{\text {нагр }}$, Вт. За незмінних значень висоти встановлення нагрівача, ступеня чорноти поверхні опромінення і в разі збільшення теплової потужності нагрівача в два рази значення відносної температури поверхні опромінення зросло на 9,7 \%.

Ключові слюва: інфрачервоний нагрівач; поверхня опромінення; ступінь чорноти; теплова потужність нагрівача. 